\title{
Use of decompressive craniectomy in TBI patients in a london major trauma centre
}

\author{
C Lopez Soto $^{1 *}$, G Sivasubramaniam², J Dawson², R Maharaj ${ }^{2}$ \\ From ESICM LIVES 2015 \\ Berlin, Germany. 3-7 October 2015
}

\section{Introduction}

Traumatic Brain Injury(TBI) is a serious health problem resulting in $1 \times 10^{6}$ Emergency admissions per annum in the UK [1]. 39\% of patients with severe TBI, or GCS less than 8 , die and $60 \%$ survive with unfavourable outcomes [[2]].The aim of TBI management is to minimise secondary brain injury from cerebral oedema to maintain brain oxygen delivery, which may be achieved via medical or surgical management, latest by using decompressive craniectomy (DC) in an attempt to reduce intracranial pressure (ICP). However, no current guidelines on its use have been published and its use remains controversial [3].

\section{Objectives}

Primarily, to describe the incidence and indication for DC in a Major Trauma Tertiary Centre.Secondly, to further evaluate ICU and in-hospital mortality rates in those patients treated medically vs those who were decompressed.

\section{Methods}

We retrospectively collected the following data in all TBI patients admitted to our institution over a 3yr period from July 2011-July 2014:gender, age, APACHE score, presenting GCS. For those patients who received DC, we recorded the indication to proceed to surgery. ICU and Hospital mortality was recorded in all patients. Glasgow Outcome Score was recorded in all that was documented.

Descriptive statistics were used to report data.

\section{Results}

Over the3 year period,481 patients were admitted to the ICU with a diagnosis of TBI.Demographic data is shown on Table 1. Forty-seven patients $(9.77 \%)$ received DC. In 25(53.19\%),decision was based on initial scan and examination and in 22(46.81\%) on ICP refractory to medical managementICU mortality was $25.53 \%$ of those who got DC compared to $12.89 \%$ of all patients medically treated and both ICU and Hospital mortality were higher in patients who received DC.Unfortunately, only 47 patients (9.8\%) had a documented GOS.

\section{Conclusions}

Use of DC in our institution is in keeping with current published data $[[4,5]]$. Both ICU and hospital mortality were higher in patients who received DC than those medically treated. Although this may be attributed the former being more severely injured, we think that further studies need to be done.Unfortunately, the lack of documented data on GOS rendered us unable to analyse this feature of management.As a TBI follow-up clinic has been set up in our trust, we hope to study the effect of DC on neurological outcome in the near future.

Table 1 Patient demographics.

\begin{tabular}{ll}
\hline Gender & Male $370(76.92 \%)$ Female $111(23.07 \%)$ \\
\hline Age (yrs) & 46.8 \\
\hline APACHE Score & 15.28 \\
\hline First GCS documented & $15-13: 107(22.25 \%) 12-9: 101(20.99 \%) \leq 8: 267(55.51 \%)$ Not recorded: $6(1.25 \%)$ \\
\hline
\end{tabular}

${ }^{1}$ Norfolk \& Norwich University Hospitals, Anaesthetics \& Intensive Care, Norwich, United Kingdom 


\section{Authors' details}

'Norfolk \& Norwich University Hospitals, Anaesthetics \& Intensive Care, Norwich, United Kingdom. ${ }^{2}$ King's College Hospital, Critical Care, London, United Kingdom.

Published: 1 October 2015

\section{References}

1. Li L, Timofeev I, Czosnyka M, Hutchinson PJ: The Surgical Approach to the Management of Increased Intracranial Pressure After Traumatic Brain Injury. Anesth Analg 2010, 111(3):736-748.

2. Rosenfield JV, Maas Al, Bragge P, Morganti-Kossmann MC, Manley GT, Gruen RL: Early management of severe traumatic brain injury. Lancet 2011, 380(9847):1088-1098.

3. Ahmad FU, Bullock R, Bullock R: Decompressive craniectomy for severe head injury. World Neurosurg 2011, 75(3-4):451-453.

4. Nirula R, Millar D, Greene T, McFadden M, Shah L, Scalea TM, et al: Decompressive craniectomy or medical management for refractory intracranial hypertension: an AAST-MIT propensity score analysis. Trauma Acute Care Surg 2014, 76(4):944-952.

5. Cooper J, Rosenfeld JV, Murray L, Arabi YM, Davies AR, D'Urso P, et al: Decompressive Craniectomy in Diffuse Traumatic Brain Injury. N Engl J Med 2011, 364(16):1493-1502.

doi:10.1186/2197-425X-3-S1-A489

Cite this article as: Lopez Soto et al:: Use of decompressive craniectomy in $\mathrm{TBI}$ patients in a london major trauma centre. Intensive Care Medicine Experimental 2015 3(Suppl 1):A489.

\section{Submit your manuscript to a SpringerOpen ${ }^{\odot}$ journal and benefit from:}

- Convenient online submission

- Rigorous peer review

- Immediate publication on acceptance

- Open access: articles freely available online

- High visibility within the field

- Retaining the copyright to your article 